\title{
Vocabulary Analysis on an English book for Primary School Students in China
}

\author{
Yongheng Wang * \\ School of Foreign Languages, Southwest University for Nationalities, Chengdu 610041, China \\ 1532698155@qq.com
}

Keywords: Vocabulary analysis, young learners, English course book, primary schools.

\begin{abstract}
Words are the building blocks of language and having a good supply of them is very important for students' right from their beginning English learning. The sooner students are able to communicate with each other in English, the more motivated they will be. Having enough vocabulary for them to draw on is the prerequisite. Furthermore, without an extensive vocabulary, students will be unable to use the language structures and functions they have learnt for comprehensible communication, both productively and receptively. This paper aims to analyze the vocabulary taught in some of the primary schools in Sichuan, China and its implications for teachers' future teaching and students' learning are given.
\end{abstract}

\section{Introduction}

Words are considered as the constructive materials in English learning. Wilkins [1] states that if learners don't understand grammar, they can conveyed very little; without vocabulary, nothing could be conveyed. Harmer [2] holds the same view that vocabulary is regarded as the virtual organs and flesh of the language. Therefore, vocabulary learning plays an essential part in English learning. Pupils who are using this book starts to learn English at age 6 and most of them have no experience of learning other foreign languages before, so most of them show great enthusiasm for learning English. Keeping pupils motivated in learning English is the key point in the process of English learning. Vocabulary learning is the precondition for learning a language well. In order to let them have a good understanding of the words in their English book and thus enable them to use the target language-English, conducting a series of research on the vocabulary learning that they are going to learn is a must. Since English is not their mother language, most learning occurs in the classroom with their English coursebooks. Analysis on what words are taught in students' book, how they are taught and what is left for the teachers to think about after the research will be beneficial both to the learners and teachers. The English book (the second grade I) discussed in this paper was co-authored by Chinese and English experts in 2013 and published by FLT and RP \& MPL. The book is mostly used by $6 / 7$ years old children in their second year of learning English.

\section{Vocabulary analysis of the book}

\subsection{Vocabulary Taught in this Book.}

Since pupils have just begun to learn the foreign language, English, there is no writing involved so as to not burden their first stage of learning but make it a fun process. The vocabulary taught in this book can be grouped into three types: three-skill words, two-skill words and one-skill words.

There are 69 three-skill words which pupils are required not only to be able to listen, speak but read as well. These words are seen to be the key words that children must be able to use, both productively and receptively. They mainly consist of 61 content words among which there are 37 nouns, 7 adjectives and 17 verbs and 8 function words (see the table below). Content words are those that carry a lexical meaning, even out of context, such as nouns, lexical verbs and adjectives. Function words are those which carry no lexical meaning but carry a grammatical meaning, such as adverbial particles, auxiliary verbs, prepositions, conjunctions, determiners, pronouns and numbers [3]. Students are also 
required to learn 37 two-skill words among which most of them are taught as communicative chunks or phrases. From the figures above we know that much emphasis has been given on content words and high frequency words. Because their cognitive conception has been developed well enough for them to learn abstract words at this age it is quite reasonable for young learners to start learning vocabulary with concrete words which they can see, touch, taste and play with. In addition, 10 one-skill words which can be called receptive words are introduced to help carry out the TPR (total physical response) activity, which is the most popular and effective activity for young learners to learn the vocabulary [4]. Pupils only need to be able to understand these words and they do not necessarily need to have the ability to speak them out.

Table1. Three Skill Words [5]

\begin{tabular}{|c|c|c|c|}
\hline \multirow{2}{*}{$\begin{array}{c}\text { 68three } \\
\text { skill } \\
\text { words }\end{array}$} & \multicolumn{2}{|c|}{8 function words } & \begin{tabular}{c} 
too, on, their, how, by with, then, in \\
\cline { 2 - 4 }
\end{tabular} \\
$\begin{array}{c}\text { 60Content } \\
\text { words }\end{array}$ & 36nouns & $\begin{array}{c}\text { Soon, noodles, rice, children, icecream, banana, apple, milk, orange, } \\
\text { fruit, tomato, dress, trousers, party, lunch, home, TV, park, moon, city, } \\
\text { train, bus, bike, holiday, ship, plane, music, winter, spring, summer, } \\
\text { autumn, sweater, coat, year, hair, dinner }\end{array}$ \\
\cline { 3 - 4 } & & $\begin{array}{r}\text { 17verbs } \\
\text { have, watch, live, walk, goes, work, run, love, watches, read, come, } \\
\text { play, listen, fly, wear, eat, have }\end{array}$ \\
\cline { 3 - 4 } & 7adjectives & favourite, nice, great, warm, cool, gold, Chinese \\
\hline
\end{tabular}

\subsection{Introducing the New Words}

All the words are organized according to the topics or themes which are closely related to young children's lives. This kind of organizations is very common for vocabulary presentation because it is easy for teachers and learners to expand the vocabulary around the topics. This thematic organization can also facilitate the memorization of words [6]. Three ways of introducing new words are used in this book. Because all the key words pupils are required to learn are concrete nouns and adjectives, they can be introduced by real objects or cards which can help pupils to understand through visualization. This is the most widely used way of introducing new words in this book. Storytelling is another effective method of introducing the new words. For example, when teaching the vocabulary about the season, the teacher can tell a very simple story accompanying gestures, expressions and imitations. Besides, new words are also introduced through TPR. This is a language teaching method built around the coordination of speech and action; it attempts to teach through physical activity.

\subsection{Practice and Recycling of the New Words}

Children learn new words very quickly, but they will also forget quickly, so it is very important to give them lots of practice of the words immediately after they have learnt them. The research conducted by Seiber, Anderson and Jordan and Griffin [7] shows that most forgetting occurs immediately after initial learning and then, as time passes, the rate of forgetting becomes slower. This suggests that immediate practice after first encounter with new words is essential for learning. The more practice the learners acquire, the better they can learn. Pupils who are using this book have enough opportunities to practice the new words in each unit. There are some kinds of activities for pupils to practice the words newly learnt in each unit.

In order for the words to be retained in learners' long-term memory, they need to be me and recycled at intervals in different activities. Although the practice. Although the practice that pupils have with new words in each unit of this book is enough for them to learn, because the spaced recycling across units in this book is quite scare, it is very likely for pupils to forget then one or month later. There is only one recycling chapter at the end of the book and this is the only chapter pupils have to revise the words across units. Apparently, in the only recycling chapter pupils have very limited chances to revise all the words learnt so far. We all know that recycling of words in class is particularly important for young children who learn a foreign language because they seldom have the chance to use the language outside the classroom. In order for them to be able to learn the language successfully and thus build up their confidence for the future learning, more recycling across units or even books should be presented to them. This is what we, as teachers, need to think about. 


\subsection{Words Connections with the Grammar in this Book}

It was common to see grammar and vocabulary as separate areas of language teaching and learning. But the new work on word patterns suggests that grammar and vocabulary can actually be usefully combined because all words can be shown to have patterns [8]. Cameron also hold that the more we find out about how words work in languages and how vocabulary is learnt, stored and used, the more difficult it becomes to uphold the traditional split between vocabulary and grammar[3] . For instance, if we want to emphasize the height of a more accurately, we need to know both adjective words (cold/hot) and the grammatical adverbial word (very). This book illustrates that teaching/learning of vocabulary is connected with grammar but they are usually learnt as patterns or chunks and not learnt by teachers' direct explaining of grammar features. For example, the words about the food and grammar patters "I don't like, Do you like and Amy likes " are closely connected in Module 2, 3 and 4. In my personal view, indirect teaching of grammar is more appropriate for young children because it is difficult for them at this age to understand and tackle grammar directly. Many may argue that children can learn grammar more easily by means of direct teaching, but I personally argue that direct grammar teaching is often taught in an old fashioned method that is likely to bore the teachers as well as the children. We must bear in mind that children's interest in learning is the most important factor for them to learn successfully.

\section{Implications}

The words pupils learnt in this book are far more enough for them to use, so we need to enlarge their vocabulary learning in some other ways. Luckily, children can now meet with English through the internet, TV programmes or computer games outside the classroom. In order to satisfy their needs, teachers need to introduce some extra words to them in class. Borrowing from Lynne Cameron's ideas, three ways of introducing extra words to children can be applied while using the book [3]. Firstly, working outwards from the coursebook: start from the topic of the coursebook unit, but do not stop with the words that are given. Teachers and students can extend the words according to the thematic organization. Secondly, learner's choice: normally, vocabulary learning around a topic begins from the book rather from the learners. But in fact vocabulary learning around a topic can also begin from the learners. Students are highly motivated to learn in this way because they can choose what they want to learn, not just those words that are required of them in the book. At last, indirect learning through stories. Children all enjoy listening to stories. Elley's [9] study shows that a lot of vocabulary can be learnt through stories and the words they learn may be retained for quite a long time. Vocabulary in stories is presented in a vivid and clear context that appeals to their imagination. In addition to this, the illustrations printed in the story book help to convey the meaning. Both the context and the amusing storylines can make the vocabulary easy to remember. But if we want to take advantage of the storytelling as an effective tool for learning vocabulary, we need to choose the stories which are not only interesting to pupils, but also suit their level, not too hard and not to easy. If there are too many new words in the story, it will make no sense to the students and therefore they will learn nothing from it. The story should also be told several times. Unless the words are encountered several times they will not be reinforced and thus not remembered.

\section{Summary}

Hopefully, the above analysis and discussion will bring both teachers and pupils benefits in teaching and learning vocabulary. But what the teachers and coursebook designers should always keep in mind while trying to enlarge children's vocabulary is that, they should not only do their best to extend young learners' vocabulary, they should also bear in mind keeping pupils motivated in learning English is equally important. 


\section{Acknowledgements}

This work is supported by the Fundamental Research Funds for the Central Universities, Southwest University for Nationalities (No. 2014SZYQN82).

\section{References}

[1]. Wilkins, D.A Linguistics in Language Teaching. Edward Arnold, 1972, p56.

[2]. Harmer, J. How to Teach English. Pearson Education Limited. 2007, p106.

[3]. Cameron, L. Teaching English to Young Learners. Cambridge:CUP, P182-185.

[4]. Richards, J.and Rodgers, T. Approaches and Methods in Language Teaching. Cambridge:CUP, P36

[5]. Chenlin, Alice. English (the second grade I). 2013, FLT and RP \& MPL.

[6]. McCarthy, M. Vocabulary. Oxford:OUP. 1990, p94.

[7]. Nation, P. Learning Vocabulary in Another Language. 2001, Cambridge:CUP, P213.

[8]. Hunston.S, Francis.G\&Manning.E. Grammar and Vocabulary: showing the connections. ELT Journal 51/3, p104-108.

[9]. Elley, W. Vocabulary Acquisition from Listening to Stories. Reading Research Quarterly XXXIV(2): P 175-178 